\title{
Metaphysics, Dialectical Materialism, Maxine Greene, and Education
}

\section{Donald Vandenberg}

University of Queensland

Some recent attempts made in the educational literature to revive metaphysics, to explicate dialectics, and to claim that Maxine Greene's (1988) The Dialectic of Freedom presupposes a Deweyan metaphysics have either ignored, misjudged, or underestimated the value of her contribution to the study of education. A critical examination of the questions raised will try to show that their resolution lies in a dialectical materialism similar to the view embodied in Greene's writings. An explication of her actual "metaphysics" will illuminate dialectics and lead to a fuller statement of the nature of education when it is viewed dialectically. This will consider morality and curriculum dialectically to complement Greene's pedagogy. The dialectical perspective might help overcome the subjectivism to which phenomenological research in education is exposed. It might also enable students to find the significance in living desired by the authors who would resuscitate metaphysics.

\section{Metaphysics}

The papers urging attention to metaphysics by Allen (1991) and Arcilla (1991) are primarily concerned with the meaning of human life. The search for its generic meaning, however, has to begin with evolution of human life from the higher primates through chance mutations and the chance union of the ovum with any one of the 300-400 million spermatozoa present at conception. Metaphysics is concerned with what exists, furthermore, and human life in general does not exist. It is always someone's life: you and I and he and she exist. Allen alludes to this fact when he classifies the logical possibilities and lists proximate, individual, internal, immanent, and intrinsic meanings with their opposites (pp. 47-48). Arcilla explicitly recognizes it when raising the questions, "Who am I? Why am I? How should I live and die?" as these are asked personally when the "meaning, reason for being," of one's own life has become problematic (p. 288). Except for Allen's unkindly references to Sartre (pp. 50,54), however, neither acknowledges previous explorations of these questions in the literatures of existential or educational philosophy, as, for example, in Greene's (1963) "Imaginary Gardens with Real Toads in Them."

Neither recognizes the location of these existential questions within the individual lifespan either, although they seem to characterize the 
mid-life crisis experienced by males in urbanized societies who are undergoing estrangement from their life situation. ${ }^{1}$ Arcilla (1991) recognizes that "we" ask such questions "in our most trying moments" (p. 289), but he is apparently unfamiliar with Greene's (1973) sensemaking pedagogy, which enables students to use curriculum content to establish the meaning not of their lives as if they were worldless subjects, but of the existential situations confronting them (pp. 160176).

Allen (1991) also conflates metaphysics with axiology. He says, "I cannot see how human life could be said to have a meaning of any sort unless there were some values somewhere which in some way or other it can realize" (p. 48). Granted there are values in the universe and human existence is good. It does not follow that human life has a meaning. It is fallacious for Allen to continue, "Conversely, it [life] can be said to lack meaning ... only if ... there are no values which it can achieve." The counter-example is the carpe diem, "Eat, drink, and be merry," hedonism embodied in the Rubaiyat, where life is perceived to be meaningless despite the value of "A book of verses ... a jug of wine, a loaf of bread, and Thou." Thus Allen does not establish his thesis that if life has a meaning, then education "has a meaning, a point, or purpose" and it is "manifestly worthwhile" to educate the young "for a life that is or can be worthwhile" (p. 50). We can agree that the young should be educated for valuable lives regardless of our beliefs about a meaning of life and turn to value theory and ethics to ascertain the kind of life worth living, as Socrates does by questioning Cephalus at the beginning of the Republic. Because both Plato's Republic and Dewey's Democracy and Education begin by considering life, these paradigms of educational theory support these writers' intent to examine life as the context of education. Unfortunately, they are unfamiliar with Greene's (1967) book of readings Existential Encounters for Teachers where she first mentions the pedagogical significance of the dialectic between necessity and fulfillment, facticity and freedom, the absurd and the meaningful (pp. 163-165). ${ }^{2}$

\section{Dialectics}

So are recent attempts to revitalize dialectics in educational thought. ${ }^{3}$ Kemmis and Carr (1983) set out a concept of dialectic as the unity of opposites that is so vague it has been rightly criticized as being contrary to the ideal speech situation they advocate (Fisher, 1987, p. 39). Their conflation of Hegelian/Marxist dialectics with Aristotle's (pp. 36-39), moreover, enables them to borrow the latter's conception of praxis for their "action research" program in the kind of ideological distortion that should be cleared up by the Habermasian critical theory they profess. At any rate, Gadamer (1979) seems correct to claim, "It is not Aristotle, but Hegel who is our important witness for the dialectical alement of experience" (p. 317) 
When Hammer and McLaren (1991) "problematize" "the concept of 'dialectics' and its historical usage" (p. 23), they misunderstand Hegel. They say, "The antithesis within a contradiction ... must have a 'positive' meaning; in other words, it must have a character of its own. Hegel called this 'the negation of the negation"' (p. 26). To the contrary, according to Hegel the antithesis (with its positive aspect) is the negation of the original affirmation (or thesis). The negation of the negation is the subsequent negation of the antithesis when its positive aspect is "synthesized" with the original thesis. For example, Hegel (1969) claims that if one begins with pure, undifferentiated being, it passes over into its opposite: pure, undifferentiated nothing. Nothing is the negation of being, yet it too passes over immediately into its opposite. Of being and nothing Hegel says,

They are not the same, that they are absolutely distinct, and yet that they are unseparated and inseparable and that each immediately vanishes in its opposite. Their truth is, therefore, this movement of the immediate vanishing of one in the other: becoming. (p. 83)

Nothing is thus the negation of being. Becoming is the negation of nothing, or the negation of the negation in the "immanent synthesis of being and nothing; but ... the name synthesis, synthetic unity, has rightly been dropped" (p. 96) Instead of a synthesis of opposites, the distinction between the polarities is sublated (aufheben), that is, simultaneously preserved and cancelled (p. 107). As Adorno (1973) says, "What Hegel calls synthesis is not simply the downright new quality leaping forth from definite negation; it is the return of what has been negated" (p. 333). In a Hegelian dialectic the so-called synthesis is less a unification than a reconciliation of apparent opposites that does not cause them to disappear: the cores of the thesis and antithesis are retained in polar opposition, like the positive and negative poles of a battery. ${ }^{4}$ Hegel (1977) says, "This unity, which appears as the middle term over against the independent extremes, is a perpetual diremption of itself into just these extremes which exist only through this process" (pp. 82-83).

When Hammer and McLaren (1991) discuss the negation of the negation in Marx's dialectic (pp. 39-41), they try using it to explain historical events, supposedly "understanding reality dialectically" (p. 46). This postulates dialectic as a psychological or sociological law, rather than as an intellectual tool to organize ideas. Unfortunately, they are unfamiliar with the phenomenological understanding of the dialectic available in Greene's (1988) The Dialectic of Freedom.

The earlier formulation of dialectical humanism by Bowles and Gintis (1976) accurately retains the dialectical tension of the polarities of the individual and the community and of education for self-development and schooling for social reproduction (p. 271), ${ }^{5}$ but their advocacy of 
revolutionary socialism is insufficiently dialectical. If socialism is the negation of capitalism, the negation of the negation is a welfare state liberalism (i.e., social legislation to distribute goods more equitably) that retains the dialectical tension between the polarities of capital and labor even while mediating (or reconciling) them. Teachers who are neither radical nor socialist might support social legislation if they listen to Greene's plea (1988) to educate students to look beyond the given in the development of the praxis needed in the democratic community (pp. 124-125).

\section{Greene's Alleged Deweyan Metaphysics}

Garrison $(1990,1991)$ and Neiman (1991) are also unaware of Greene's dialectics when they debate whether Dewey's metaphysics underlies The Dialectic of Freedom. Their wealth of citations of Dewey include very few references to Greene's book itself (Neiman has none) and none to her other publications. Although Neiman thinks he is close to her when he says, "She adheres ... to the idea that whenever social critique goes well it remains true to the ordinary ... to praxis" (p. 217), this contrasts sharply with Greene's own account. After referring to the need to transcend passivity in the Preface to her Landscapes of Learning (1978), she says, "Transcendence has to be chosen; it can be neither given nor imposed" (p. 2). Then after explaining that people are more likely to "seek their own transcendence" when grounded in the landscapes of their personal lives, she claims,

literary works of art make it possible for us to come in contact with ourselves ... because, in order to enter into the illusioned world of the novel ... we must break with the mundane and the taken-for-granted. We must, as it were, bracket out the ordinary world ... [in a phenomenological] returning to "things themselves."

In other words, for Greene, ordinary life does not ordinarily involve praxis. Praxis is, however, exemplified in literature. She consequently devotes the entire third and fourth of the five chapters of The Dialectic of Freedom to the struggles for freedom of women, African-Americans, Jews, and other ethnic groups as these are manifested in novels. She had already in the second chapter interspersed fictional characters (e.g., Huckleberry Finn, Hester Prynne, Ahab, Maggie) with historical personages (e.g., Jefferson, de Tocqueville, Whitman, Du Bois) to create an historical panorama of the changing concepts of freedom in America since its foundation. Literary artists displayed an understanding of the idea of freedom concretely in the lives of their fictional creations, whereas public figures and philosophers articulated it abstractly. Greene locates Dewey's concept of freedom as intelligent planning within the Progressive Era before World War I, then again in the 1930s in the New Deal, limiting it to the pre-war era when she notes that its significance died off after World War II (pp 48, 51; cf. Greene, 1965, p. 
161). When comparing the militant socialists and communists of the 1930 s to the Deweyan rational planning of the New Deal, moreover, she reminds us of "the difference between an existential project and a program or plan deliberately carried through" (p. 50). Because Dewey does not refer to the personal project of being, reference to "existential metaphysics" and "existential experience" (Garrison, 1990, 1991) in his writings involves a misuse of terms. Greene (1983) says that even as a graduate student she found Dewey "seriously lacking in the tragic sense of life, even in an attentiveness to the human condition" (p. 3).

\section{Greene's Sartrean Metaphysics}

Greene begins The Dialectic of Freedom saying, "My focal interest is in human freedom, in the capacity to surpass the given and look at things as if they could be otherwise" (p. 3). She claims Dewey, Isaiah Berlin, Stuart Hampshire, Marxists, and Neo-Marxists agree that freedom is an achievement that occurs in "the concreteness of lived social situations" (pp. 4-5). It involves an orientation to the possible that overcomes the determinant that resembles Kant's "empirically bound, transcendentally free" but with praxis instead of reason to transcend the phenomenal world. To conceptualize praxis she turns to Sartre's tract on dialectical materialism, originally entitled Existentialism and Marxism. In this Search for a Method (1968) Sartre refers to his continuing interest in the individual who he believes should not become swallowed up in the formal dialectics of Marxism (pp. 27-29). Greene's use of literature manifests the same concern for specific people and her refusal to transcend their reality with the abstractions of a strongly conceptualized dialectic. She explains (1988) that for Sartre, "The project of acting on our freedom involves a rejection of the insufficient or the unendurable, a clarification, an imaging of a better state of things" (pp. 5, 22) apparently paraphrasing Sartre (1968) adequately:

In relation to the given, the praxis is negativity; but what is always involved is the negation of a negation. In relation to the object aimed at, praxis is positivity, but this positivity opens onto the "nonexistent," to what has not yet been. (p. 92)

Then she quotes his next words, saying praxis is a "flight and a leap ahead, at once a refusal and a realization." All this is a far cry indeed from Dewey's freedom of intelligence. The sense of the paraphrase of Sartre pervades The Dialectic of Freedom and Greene's earlier work. Any difference between her metaphysics and Sartre's dialectical materialism therefore seems accidental. ${ }^{7}$

Greene (1988) also cites the anguish (Angst, pp. 5, 46) that in Being and Nothingness Sartre says accompanies freedom (pp. 29-44). Then, after promising to show how freedom is involved in the life projects of "various human beings" as they transcend the resistance of their given situations, she again quotes Being and Nothingness to claim that it is 
only a free choice that gives meaning to resistances and obstacles. They become resistances only after one posits a goal to which they are a hindrance. The chapters on women, African-Americans, Jews, and migrants show how the literary personae have refused to accept their psychological or social conditioning or oppression and have transcended such determinants in liberating projects. The metaphysics of this negation of the negation for her, however, is neither Hegel's nor Marx's. Greene (1988) says she wants to break through the

persisting either/ors. There is, after all, a dialectical relation marking every human situation: the relation between subject and object, individual and environment, self and social, outsider and community, living consciousness and phenomenal world. (p. 8)

She claims that the dialectic between the apparent opposites presupposes their mediation in an enduring tension, adding: "Nor is it the kind of dialectic that can finally be resolved in some perfect synthesis or harmony," citing Merleau-Ponty (1968, p. 95) on the limitations of all surpassings in both thought and life. Each person's life is conditioned by environment, social class, economic status, bodily make up, and so on, that is, by what Sartre calls facticity. The freedom enabling one to overcome these conditions achieves only a partial, temporary transcendence of facticity (p. 9).

Greene (1988) explicitly dismisses Dewey's conceptual synthesis because his model of intelligence is deemed unable to cope with the dehumanizing political and economic forces operative in society (pp. 39-40, 43-44). She seems to accept what Sartre (1968) calls "the irreducibility of human praxis" (p. 87) and cites endlessly throughout The Dialectic of Freedom instances where genuine praxis appears in literature or history, apparently implementing what Sartre's translator (1968) calls "a Marxism which reinstates the individual and his [or her] praxis at the very heart of history" (p. xxx). She explicitly acknowledges using Sartre's framework to interpret the texts when she summarizes a chapter saying, "The Sartrean notion that freedom can be achieved only in a resistant world was played out in many female lives" (p. 67).

Greene's acceptance of Sartre's (1968) special metaphysics, which he calls a "concrete anthropology" or a "structural, historical anthropology," (pp. xxxiv, 84) can be shown in detail through an examination of her earlier work. It should be noted first, however, that her main structural concepts in The Dialectic of Freedom are wide-awakeness, landscape, being in the world, futuring, possibilities, and Arendt's opening a space for one's appearance and keeping promises to establish personal continuity. ${ }^{8}$ These categories were more fully elaborated in Landscapes of Learning, ${ }^{9}$ in her (1973) Teacher as Stranger, ${ }^{10}$ and more 
technically formulated in Vandenberg's (1971) Being and Education. ${ }^{11}$ They are not at all similar to Dewey's "metaphysical" categories.

In Teacher as Stranger (1973), her magnum opus, Greene explicitly repudiates Dewey's theory of knowledge and its underlying metaphysics with the claim it "was concerned with calculative or objective thinking," for this technologizing of consciousness transforms existence into something it is not because of the will to power, its endeavor to control what cannot be controlled, and its embodiment of what Sartre calls bad faith (p. 136). She says "teaching happens" when the teacher engages in "what Sartre has in mind when he speaks of knowing as praxis opening into "what has not yet been" (p. 172) quoting from the same page of Search for a Method quoted in The Dialectic of Freedom (and above). When Greene speaks of freedom, she always means the freedom of the spontaneity of the wide-awake stream of consciousness that Sartre (1956) refers to when he says we are "condemned to be free" (p. 439). In Landscapes of Learning Greene again quotes the same page from Search for a Method about praxis in another explicit rejection of the Deweyan interpretation of praxis (pp. 99-100, 123). ${ }^{12}$

It is, therefore, an egregious error (Garrison, 1990) to claim that Sartre's "paradox" of achieving freedom in a resistant world that Greene cites "is resolved when we recognize the metaphysical dialectical unity of opposites in experience pointed out by Dewey" (p. 200). It commits the fault Dewey (1951) himself found in his writing when he said, "I have usually, if not always, held an idea first in its abstract form, often as a matter chiefly of logical or dialectic consistency or of the power of words to suggest ideas" (pp. 44-45), adding that he was often guilty of schematizing far in advance of any explicit content to his ideas. ${ }^{13}$ In other words, Dewey himself said he did what Merleau-Ponty (1968) called a bad dialectic (in the paragraph Greene cited). A good dialectic "is conscious of the fact that every thesis is an idealization," whereas a bad one assembles a set of statements (thesis, antithesis, synthesis) and assumes that the aggregate "recomposes being" (p. 94).

\section{Greene's "Dialectical Materialism"}

The metaphysical question at hand is whether existence determines consciousness, or whether consciousness determines existence. In the Preface to the first German edition of Capital, Marx said,

My standpoint, from which the evolution of the economic formation of society is viewed as a process of natural history, can less than any other make the individual responsible for relations whose creature he socially remains, however much he may subjectively raise himself above them. $(\operatorname{vol} 1, \text { p. } 21)^{14}$

Marx is saying that he is using the methods of the natural sciences to investigate the history of economics. From this viewpoint, adopted for 
heuristic purposes, the individual remains determined by economic relations: existence determines consciousness. Marx is not, however, asserting a general economic determinism on a cosmic scale. Even if he is read that way, he admits the individual "may subjectively raise himself above" economic relations. Then consciousness determines existence within the economic circumstances. Thus Marx might agree with Sartre's (1960) statement:

We conceive with no difficulty that a man may be a center of irreducible indetermination, although his situation conditions him totally. This unforeseen area which stands out of the social field, is what we call freedom and the person is nothing else but his freedom.... We do not do what we want; however, we are responsible for what we are: this is the fact. Man, simultaneously explained by so many causes, is still alone to bear the burden of himself. In this sense, freedom could be considered as a curse, it is a curse. But it also is the unique source of human grandeur. On this fact, the Marxists will agree with us in spirit ... because they do not hesitate ... to express moral condemnations. (p. 441)

Be that as it may, the phenomenological problem is to keep the terms of inquiry from diverting description into speculative constructions about "the metaphysical unity of opposites in experience." It is to return to the things themselves.

A paradigm case of existence determining consciousness is addiction. Someone who quits smoking, drinking coffee, or using any addictive substance remains free in relation to it only by resisting organically caused impulses to smoke, and so forth. Succumbing to them lets facticity take over. Stopping one's use of an addictive substance thus exemplifies consciousness determining existence. The free choice to stop enables one to interpret the desire for it as a withdrawal symptom that should be resisted. Similarly, for Sartre all praxis contains both freedom and facticity. The "paradox" occurs only when one reifies freedom apart from the human engagement with the world in some form of inauthentic existence. Greene (1988) illustrates this concretely by recounting Kundera's (1984) The Unbearable Lightness of Being (pp. 9-10). As Sartre (1956) says, "What we call freedom is impossible to distinguish from the being of "human reality" ( $p$. 25). The being of human existence is consciousness. Consciousness is human existence. Neither determines the other because an existing consciousness and a conscious existence are one and the same thing considered from different aspects. The wider awake one is, the more conscious one is and the more freely one can transcend facticity.

Much of Western metaphysics has erroneously identified consciousness with conceptual processes, rather than with the sentience of the whole body. In the phenomenon of praxis, that is, of authentic or wide-awake existence, however, freedom is always an engaged freedom (Sartre, 1956, pp. 37, 495). Authentic praxis "synthesizes" freedom and fac- 
ticity, that is, consciousness and facticity, that is, consciousness and existence. In other words, praxis involves mind and body, conceptual and perceptual awareness of things, and so on, each affecting the other in mutual reciprocity, that is, dialectically. Greene (1988) quotes Merleau-Ponty on the impossibility of determining the share contributed by the situation and by freedom to explain his claim that there is never complete determinism and never complete freedom (p. 98). The details of the interaction are idiosyncratic to the situation as an historical event in the lives of specific individuals. The elements of praxis are "synthesized" practically, uniquely, in historical events now and then, not theoretically in some meta-narrative or metaphysics that would dictate programmatically what praxis should be like.

Greene (1973) cites Sartre's claim that one is always in a situation, free to choose among "multiple possibilities" only from a "background of necessity" (p. 255). In this sense she believes existence determines consciousness, but dialectically: wherever multiple possibilities exist, one is free to choose from among them. She consequently supplies (1988) the particulars of a great many historical and fictional persons struggling for their freedom in a kind of concrete anthropology. She would probably deny that there is an essence of human nature that needs to be developed for someone to be free..$^{15}$ She would, however, probably agree with Ferry and Renaut (1990) that

man's humanitas or Eigentlichkeit lies in his capacity to wrench free of his determinations (which Kant called "freedom," Husserl "transcendence," Sartre "existence," Heidegger "eksistence," and Arendt "action") in nothingness understood as the absence of definability by a general code. (p. 95)

It is abundantly manifest that she accepts that the essence of the human being is existence: it is authentic existence, that is, freedom understood as the projection into futural possibilities, as transcending the given in a project of being. It is clear that she accepts a structural anthropology that is identifiable as dialectical materialism.

One of these words is in the title of her latest book. The indebtedness to Sartre in the interpretation of specific people's lives in fiction in it is equally manifest. In addition to the reference to "many female lives," she says, "We can return to Sartre's notion of interpretation: Bigger's vision was of a world that had no mercy for him" (p. 97). More abstractly, she says, "Human consciousness, moreover, is always situated; and the situated person, inevitably engaged with others, reaches out and grasps the phenomena surrounding him/her from a particular vantage point and against a particular background consciousness" (p. 21). The word materialism for the intentionality of consciousness might not be too strong if Adorno (1973) is correct to say, "It is by passing to the object's preponderance that dialectics is rendered materialistic" (p. 192 ), and considering that immediately before this Greene said con- 
sciousness "is not to be understood as an interiority." She is silent about interiority, or inwardness, which is at most a reflexive stream of awareness, not a substantive entity located behind the eyeballs. If there is no "ghost in the machine" for Greene, neither is it a machine. It is a human being. If identifying Greene's perspective as dialectical materialism seems too deterministic, it is at least what Adorno (1973) calls a materialist dialectics (pp. 198, 200). As Merleau-Ponty sais, it is not so much that consciousness is embodied as it is the body that is conscious, at least when awake.

Greene's frequent citation of Merleau-Ponty is noteworthy. Although the concluding chapter of his Phenomenology of Perception (1962) is about freedom in a view that seems compatible with Being and Nothingness, his criticism of the latter was instrumental to Sartre's shift to the quasi-Marxism of Search for a Method (Dreyfus \& Dreyfus, 1964, p. $\mathrm{xx})$. It also reflects Greene's orientation (1983, p. 4). It is too much to say she has a metaphysics of dialectical materialism if it suggests a closed synthesis that dishonestly ends the dialectic. On the other hand, its import is embodied in the three books mentioned and in the frame of reference accepted by Greene since 1967 when she said about the student, "We must foster the freedom that he [or she] can attain as he [or she] moves dialectically between necessity and fulfillment, between the ineradicable qualities of his [or her] particular situation and the thus-far-unrealized capacities which are his [or hers]" (p. 163). Suffice it to say that the way Greene accepts the dialectical principle precludes her acceptance of a metaphysics as a cosmology.

The relevance to pedagogy is treated in her earlier work (1973, pp. $160-176 ; 1974 ; 1978$, pp. 95-110). It is not repeated in The Dialectic of Freedom, where she relies instead on the theme of her very early work (1957) regarding what philosophy of education can learn from literature, which is merely "the business of creating images of human dignity" (1963, p. 182). Her chapters on the struggles of "various people" for freedom do not presuppose her metaphysics so much as express it. Her answer to the question, What is real? is individual people with proper names, all with their own value and dignity, who have their being in the world, and who do not exist separately from their dialectic with the world. Existing individual people, however, are not the only real things. Equally real for Greene (1985) are the "material dimensions of lived situations" in which they find themselves (p. 76). Her literary metaphysics of the particular person is materialistic in the sense that it does not reify transcendence, mind, consciousness, the person, freedom, or anything at all. It is only about human beings. It is not about the natural world as it exists independently of human beings, for which Greene (1957, p. 143; 1963, p. 170) acknowledges the authority of the natural sciences. It is dialectical because it does not separate people from becoming who they can become in the world with others, 
because it reflects a lifelong commitment "to the concrete, developing, ambivalent person in his [or her] unique potentiality" (1962, p. 87).

Greene does not explicitly claim that meaning is established in one's life through the pursuit of existential projects that freely transcend the given. She suggests (1988), however, that the inability to transcend facticity leads to the suicide of two fictional heroines (pp. 41, 63-64), which presupposes that one gains a sense of the significance of one's life and of its worthwhileness through the active engagement with the resistances of the world in a project of being.

\section{The Dialectic in Ethics and Moral Education}

Her ambivalence toward so-called feminist ethics and moral education might have been resolved had she treated ethics and moral education dialectically. She claims (1988) that neither Noddings nor Gilligan refer to freedom when they discuss women's ethics, and she expresses doubts: "Mutuality and concern (if, indeed, they characterize most women's lives) are not in themselves enough to change the world; nor is the affirmation of responsibility for others" (p. 85). Before she subsequently suggests that caring teachers should look out at the world with their students to help them make sense of the world, however, she quotes Gilligan, "Woman's place in man's life cycle is to protect" the importance of attachment (p. 120), apparently approvingly and falling prey to the stereotyping she questions. Noddings' $(1984,1989)$ ethics of caring, in other words, is militantly explicated as the antithesis, or negation, of "masculine" ethics. It is quite innocent of the history of normative ethics, and no "synthesis" with "male ethics" lurks within her horizons. The various dialectics Greene says exist in every situation, however, include the relation between the masculine and the feminine, not merely between people but also within individuals regardless of gender (Datan, 1976).

Greene may recognize this dialectic. She says (1988) that in contrast with freedom, liberty is "embodied in laws or contracts or formulations of human rights," before she rejects the proposals to educate for autonomy through verbal means that arise from Kohlberg's work (pp. 117, 119). The dialectic in morality, however, is not so much between masculine and feminine as it is between the right and the good. The affirmation of morality as doing the right thing to fulfill moral obligations (that is, truth-telling, promise-keeping, non-maleficence, beneficence, etc.) was expressed by Moses and then within the Enlightenment faith in the deontological ethics of Kant, Ross, and Kohlberg (stages 4 and 6), for example. The negation of morality by realizing the good instead of doing one's duty was advocated by Jesus and then within the Enlightenment faith in the teleological ethics of Bentham, Stuart Mill, and Dewey, wherein the concern for social welfare promotes the greatest good of the greatest number. The nega- 
tion of the negation (Vandenberg, 1990) occurs in the human rights ethics that includes, among other things, rights to such goods as food, clothing, shelter, medical care, and education, as well as the moral obligations to honor them even in the absence of caring for others.

In historical perspective, the ethic of caring is merely the current version of the ethics of doing good instead of right, most notably expressed by Jesus, who did not, however, neglect the dialectic with moral rules when he told the rich young man to obey the commandments (Matthew 19: 17-19). Had Noddings recognized her view as a contemporary version of antinomianism, she might have realized there can only be one morality that includes masculine and feminine components in dialectical relation. A dialectical ethics mediates the polar opposites of caring and acting on principle, moral feeling and moral reasoning, wanting to do good and being obliged to do one's duty, and so on. With a dialectical ethics that reconciles moral sensibility and moral conceptualization, Greene need not have been so dismissive of moral reasoning processes in classrooms. They can articulate the moral sensibility that students have been developing in the so-called hidden curriculum of schooling and elsewhere to help them freely transcend facticity in the moral realm and channel their struggles for freedom through the framework of liberty as "embodied in laws or contracts or formulations of human rights." To keep it from becoming merely verbal, the dialectic with the perceptual world, or praxis, should be maintained.

\section{The Dialectic in the Curriculum}

How praxis can be maintained in students' lives in general requires a dialectical perspective of the whole curriculum. Bowen and Hobson (1987) claim, "There has been a dialectic of education in operation throughout the centuries" between the intellectualistic thesis and the progressive antithesis (p. 13). The affirmation of traditional liberal education is expressed by Hirst and Peters (1970) in their emphasis on the conceptual aspects of traditional academic subjects (mostly humanities) taught didactically to provide education "for those who are gifted enough to benefit from it" (Peters, 1966, p. 87). The negation of their conceptual approach appears most strongly in the progressive theories of common education of Spencer and Dewey, who emphasize the perceptual aspects of object lessons, active occupations, and natural science taught heuristically for the utilitarian aspects of every child's life. The former builds the curriculum from the top down. It claims the best knowledge in society should be given to the most academically able students at university level, then arranges the program in the primary and secondary schools accordingly. Its antithesis builds the curriculum from the bottom up. It claims the content of the school curriculum should be selected according to the natural development and interests of the young. These polarities have to be retained in dialectical relation, 
for unless one has both, one loses both and gives away the education of the working class.

A negation of the negation, or "synthesis," appears, for example, in Broudy's $(1981,1988)$ conception of a general education comprising the most general kinds of knowledge that everyone should possess, that balances the humanities and sciences, and is selected and organized to facilitate its subsequent use in evaluating the credibility of the experts to whom citizens in advanced industrial societies are exposed. If his view seems too conservative to reconcile the polarities of intellectualistic and progressive education, a statement from his first major work (1954) should be compared with one by Engels. Broudy says that for their self-determination, all people

need knowledge which enables them to understand their relations to a physical environment, a social environment, and an environment constituted by their own psychic life, or what we might call the life of the self. Every man [and woman] has to live in a physical world which behaves according to natural laws, with other people in a social order that has laws of its own, and, finally, with himself [or herself]—a Self that develops happily or otherwise according to the laws of human nature. (p. 184)

This understanding the "laws" of the natural, social, and human worlds is compatible with its Greene-ish cast in Engels' claim:

Freedom does not consist in an imaginary independence from natural laws, but in the knowledge of these laws and in the possibility which is thus given of systematically making them work toward definite ends. This holds good in relation both to the laws of external nature and to those which govern the bodily and mental existence of men [and women] themselves. (Sayers, 1985, p. 206)

If Broudy's emphasis on conceptual learning, however, encourages students with less abstractive ability to memorize what they cannot understand, the praxis restored to schooling by object lessons and active occupations becomes lost in spite of his preference for heuristics before high school.

The negation of Broudy's affirmation of general education, therefore, occurs with the strong emphasis on the intentionality of consciousness-and praxis-in the pedagogies of Freire and Greene. Like Dewey, however, their focus on pedagogy precludes (a) the formulation of a macrocosmic view of curriculum, and (b) the student's acquisition of an organized body of knowledge. Greene seems to accept the curriculum of the schools as it is given. She (1973) mentions physics, economics, and history (p. 174) and refers (1988) to the social and natural sciences, recommending "the growth of feelings of connection between human hands and minds and the objects of study, whether they are rocks or stars or memory cores" (p. 128) but then she refers to whales from the last chapter of Moby Dick. She says more about 
history, where the teacher can ask students to interpret things and thereby transcend the given $(1973$, pp. 164-167; 1988, p. 127). She treats the arts and literature more fully (1988), although, except for a brief reference to the dance, she is concerned with appreciation of paintings, poems, and fiction and their capacity to defamiliarize the given (pp. 129-133). It takes art production to promote more than a praxis of the imagination, however, as she recognizes (1978) when she says, "Visions are made real when they are transformed into perceptual realities and given intelligible form," in a discussion of the arts as making material things (p. 187).

Several things are required to negate Freire's and Greene's negation of an architectonic of general education, to reconcile it with a view like Broudy's (Vandenberg, 1990, pp. 200-220). To mediate the mind/body dialectic and ensure praxis, a wide range of activities in the arts, crafts, and trades should be included as one strand of the primary school curriculum, followed by a depth study in at least one art, craft, or trade throughout high school. This is from Dewey, but not pedagogically, and occupying only one strand of the curriculum. It should enable students to learn how to use their hands, become perceptually aware of the qualities and textures of materials, and engage in praxis on a bodily level. There should also be a broad range of the games and sports of childhood as one strand in the primary school curriculum and a depth study in at least one sport or the dance throughout high school to enable a holistic, bodily praxis and to give every student the basis for freely transcending the given in praxis throughout life in a hobby and sport.

Work in the arts, crafts, and trades, moreover, can give students sufficient confidence in their hands to conduct laboratory work in the natural sciences properly and to realize the significance of the material conditions of the discovery of scientific knowledge. Needless to say, laboratory work maintains the dialectics between the hand and the mind and between the perceptual and conceptual components of scientific knowledge. The latter may be more fundamental educationally than the dialectic between freedom and facticity, pace Greene, because reflective, conceptualizing consciousness needs to have a prereflective awareness of something in the world to reflect on and conceptualize. This should overcome the alienation from the world allegedly resulting from an overemphasis upon conceptualization inherent in the Enlightenment faith. As Adorno says, "Insight into the constitutive role of the non-conceptual in the concept would end the identity-constraint which conceptualism entails" (Dallmayr, 1991, p. 38). Then, too, simply becoming aware of something new in the world in a factual manner, learning about something, is an act of freedom. 
The dialectic between necessity and the possible, moreover, requires the acquisition of knowledge about many things in the world. The greater one's knowledge of the factual aspects of a situation, the greater the awareness of what is factically possible. As Sartre (1956) said of consciousness, "It is in this world and no other that its freedom comes into play" (p. 521). He (1974) also said, "The exploited classes ... do not need an ideology.... They need knowledge of the world in order to change it" (p. 259). Learning what is possible, therefore, requires the acquisition of a great deal of knowledge about the human, societal, and natural worlds in the humanities and social and natural sciences in order to become aware of the possibilities for genuine praxis in adult life. It has to be perceived not as knowledge but as about the human, societal, and natural worlds, however, to maintain the dialectic with the world that constitutes a free existence.

This article considers various recent claims that metaphysics and dialectics are pertinent to educational theorizing in conjunction with the writings of Maxine Greene to show that her materialist dialectics, apparently overlooked in these claims, seems phenomenologically and educationally sound when accompanied by further dialectical analysis in the areas of ethics and moral education and the content of the organized school curriculum. Her pedagogy of using curricular content to make sense of the world, consequently, can serve to promote the aim of education-a worthwhile life of perceived personal significanceespecially if is applied to specific situations through domain-specific phenomenological pedagogical research.

Notes

1. The existentialists published their main works by their late 30s: Kierkegaard, Concluding Unscientific Postscript, 33; Nietzsche, Thus Spake Zarathustra, 39; Jaspers, Psychology of the Weltanschauungen, 36; Marcel, Metaphysical Journal, 38; Heidegger, Being and Time, 38; Sartre, Being and Nothingness, 38; and Merleau-Ponty, Phenomenology of Perception, 37.

2. Allen (1989) erred to claim, "Since 1960, the only work which has used metaphysics constructively within philosophy of education has been Reid's (1962) Philosophy and Education" p. 169. Besides Greene, he overlooks at least Broudy (1961), Phenix (1964), and Vandenberg (1971).

3. This is not wholly true of Giroux $(1981 ; 1983)$, who acknowledges his debt to Greene the first time he says: "Once students become aware of the dignity of their own histories and perceptions, they can then make a leap to the theoretical and begin to examine critically the truth value of their meanings and perceptions, particularly as they relate to the dominant culture" (pp. 123-124; p. 203). He refers to Greene (1975): "The original perceptual reality continues as the ground of rationality, the base from which the leap to the theoretical is taken" (p. 304; also in Greene, 1973, p. 161).

The point was earlier stated dialectically (Vandenberg, 1971) to reconcile "the partial truth of polar values. Human existence is found 'between' landscape and geography, however, because one attains geography by the leap from landscape.... Human existence has its being in the leaping... Schooling provides the place to leap to" (p. 105). 
4. Hegel (1977) also illustrates polarity with electricity ( $p$ p. 92-93, 97-98). The point is crucial, for when Harris (1979), for example, differentiates dialectical from logical contradictions, he gives examples of the latter to be negated, rather than cases of polarities to be reconciled (pp. 122-126).

5. Giroux's (1981) attempt to refute them attacks the reproduction thesis without reconciling it with its opposite. This failure to grasp the partial truths of polar values defeats his exposition of dialectics, where he uses transcendence to render Aufhebung, as did a 1929 translation of Hegel's Science of Logic. To say an affirmation and its negation are transcended ignores their retention and reconciliation as polarities. Giroux's consequent negativism illustrates Bernstein's (1992) thesis: "It is Hegel who teaches us over and over again to be alert to the uncanny ways in which radical gestures of opposition and negation are complicit with, and parasitic upon what they are presumably rejecting" (p. 308).

6. Giroux (1992) misquotes this fragment and wrongly imputes an educational context to Sartre without saying that Greene, mentioned six lines later, is his source (p. 9).

7. But note the qualification by Stewart and Mickunas (1990): "Sartre disagrees with the deterministic interpretation of man as suggested by dialectical materialism, which sees man only as a product of social and economic conditions. But Sartre is in agreement with the basic Marxist contention that man realizes himself only in action" (p. 75).

8. Wide-awakeness, p. 23; landscape, pp. 21-22; being in the world, pp. 3,21, 57, 100, 101,120 ; futuring, p. 22 ; possibilities, pp. 2, 5, 13, 16, 23, 43, 55, 59, 72, 102, 109, $119,128,130,131,134$; Arendt's space for one's appearance, pp. $3,17,36,52,86$, 116,134 ; and Arendt on promising, p. 51.

9. Wide-awakeness, pp. 2, 4, 17, 32, 37, 42-43, 48, 84, 152-153, 163, 165, 173; landscape, pp. 2, 15-16, 19, 29, 37, 39, 102-103, 216, 220221; being in the world, pp. $14-15,17,79,106,201,213$; futuring, pp. $3,39,61,80,107,121,173,182$; and possibilities, pp. 18-19, 82, 85, 172 .

10. Wide-awakeness, pp. $6,11,163,273,295$; landscape, pp. 160161,208 ; being in the world, pp. 131-132; futuring, pp. 84, 167; and possibilities, pp. 84, 149, 163, 187, $255,279$.

11. Wide-awakeness, pp. 3-6, 7, 8, 9, 21, 32, 44, 93, 149-150, 154156, 158, 159, 162 , $170,174,177,200$; landscape, pp. 80-82, 84-90, 93, 94-96, 97, 99, 100-101, 103, 104, $105,138,144,159,170,177-182$; being in the world, pp. $32,76,82,99,133,139$, $148,150,163,199,200,201$; futuring, pp. 4, 54, 80, 89, 154-155, 174-175; possibilities, pp. 10-11, 47, 54, 55, 61, 63, 64, 65, 66, 68, 69, 70, 71, 80, 81, 85, 87, $89-90,96,101,104,106,111,120,126-128,136,138-142,146,148,149,150$, $154155,156,160,165,170,174,181,183,185,186,189,200,206$; Arendt's space for one's appearance, pp. 138, 217 n. 6; and Arendt on promising, pp. 196.

12. Also quoted in Greene (1974, p. 215); (1985, p. 75); and (1986, p. 494).

13. Bernstein (1992) concurs: "One reason that the 'classical' pragmatism of Peirce, Dewey, Mead, and James went into eclipse is because many thinkers began to feel that the pragmatic attempt to soften and blur all philosophical distinctions had the unfortunate consequence of depriving us of the analytic tools needed for clarifying and getting a grip on important differences that make a difference, and resulted in a bland undifferentiated monotonous holism" (p. 235).

14. For this issue in Marx's larger context, see Smith (1985).

15. As Haldane (1989) claims: "Education is aimed at developing our essential nature by systematically cultivating various capacities in accordance with their inbuilt structure and teleology," to explain which "The idea of human persons as rational agents is necessary" (pp. 174, 178).

\section{References}

Adorno, T.W. (1973). Negative dialectics (E.B. Ashton, Trans.). New York: Seabury.

Allen, R.T. (1989). Metaphysics in education. Journal of Philosophy of Education 23(2), 159-169. 
Allen, R.T. (1991). The meaning of life and education. Journal of Philosophy of Education, 25(1), 47-57.

Arcilla, R.V. (1991). Metaphysics in education after Hutchins and Dewey. Teachers College Record, 93(2), 281-289.

Bernstein, R. (1992). The new constellation: The ethical-political horizons of modernity/postmodernity. Cambridge, MA: MIT Press.

Bowen, J., \& Hobson, P.R. (1987). Theories of education: Studies of significant innovation in western educational thought. New York: Wiley.

Bowles, S., \& Gintis, H. (1976). Schooling in capitalist America: Educational reform and the contradictions of economic life. London: Kegan Paul.

Broudy, H.S. (1954). Building a philosophy of education. Englewood Cliffs, NJ: Prentice-Hall.

Broudy, H.S. (1961). Building a philosophy of education (2nd ed.). Englewood Cliffs, NJ: Prentice-Hall.

Broudy, H.S. (1981). Truth and credibility: The citizen's dilemma. New York: Longman.

Broudy, H.S. (1988). The uses of schooling. New York: Routledge.

Dallmayr, F.R. (1991). Life-world, modernity and critique: Paths between Heidegger and the Frankfurt school. London: Polity.

Datan, N. (1976). Male and female: The search for synthesis. In J.F. Rychlak (Ed.), Dialectic: Humanistic rationale for behavior and development (pp. 44-52). Switzerland: Karger.

Dewey, J. (1951). Biography of John Dewey. In P.A. Schilpp (Ed.), The philosophy of John Dewey (pp. 3-45). New York: Tudor.

Dreyfus, H.L., \& Dreyfus, P.A. (1964). Translators' introduction. In M. Merleau-Ponty Sense and nonsense (pp. ix-xxvii). Evanston, IL: Northwestern University Press.

Ferry, L., \& Renaut, A. (1990). Heidegger and modernity (F. Philip, Trans.). Chicago: University of Chicago Press.

Fisher, J. (1987). Kemmis's idea of dialectic in educational research and theory. Educational Philosophy and Theory, 19(1), 29-40.

Gadamer, H.-G. (1979). Truth and method (W. Glen-Doepel, Trans.). London: Sheed \& Ward.

Garrison, J.W. (1990). Greene's dialectics of freedom and Dewey's naturalistic existential metaphysics. Educational Theory, 40(2), 193-210.

Garrison, J.W. (1991). Does metaphysics really matter for practice? It depends on the practitioner. Educational Theory, 41(2), 221-226.

Giroux, H.A. (1981). Ideology, culture, and the process of schooling. London: Falmer.

Giroux, H.A. (1983). Theory and resistance in education: A pedagogy for the opposition. South Hadley, MA: Bergin \& Garvey.

Giroux, H.A. (1992). Educational leadership and the crisis of democratic government. Educational Researcher, 21(4), 4-11.

Greene, M. (1957). The uses of literature. Educational Theory, 7(2), 143-149.

Greene, M. (1962). The Enlightenment faith and the public school. In R.E. Mason \& G. $\mathrm{K}$. Pratt (Eds.), Proceedings of the eighteenth annual meeting of the Philosophy of Education Society (pp. 80-89). Lawrence: University of Kansas.

Greene, M. (1963). Imaginary gardens with real toads in them: The literary experience and educational philosophy. In Proceedings of the 19th annual meeting of the Philosophy of Education Society (pp. 170-192). Lawrence: University of Kansas.

Greene, M. (1965). The public schools and the private vision: A search for America in education and literature. New York: Random House.

Greene, M. (1967). Existential encounters for teachers. New York: Random House.

Greene, M. (1973). Teacher as stranger: Educational philosophy for the modern age. Belmont, CA: Wadsworth.

Greene, M. (1974). Countering privatism. Educational Theory, 24(3), 209

Greene, M. (1975). Curriculum and consciousness. In W. Pinar (Ed.), Curriculum theorizing: The reconceptualists. Lerkeley: McCutchan.

Greene, M. (1978). Landscapes of learning. New York: Teachers College Press. 
Greene, M. (1983). How I came to phenomenology. Phenomenology + Pedagogy 1, 3-4.

Greene, M. (1985). Consciousness and the public space: Discovering a pedagogy.

Phenomenology + Pedagogy, 3, 69-83.

Greene, M. (1986). Philosophy and teaching. In M. Wittrock (Ed.), Handbook of research on teaching ( 3 rd ed., pp. 479-501). New York: Macmillan.

Greene. M. (1988). The Dialectic of Freedom. New York: Teachers College Press.

Haldane, J. (1989). Metaphysics in the philosophy of education. Journal of Philosophy of Education, 23(2), 171-183.

Hammer, R., \& McLaren, P. (1991). Rethinking the dialectic: A social semiotic perspective. Educational Theory, 41(1), 23-46.

Harris, K. (1979). Education and knowledge: The structured misrepresentation of reality. London: Routledge \& Kegan Paul.

Hegel, G.W.F. (1969). Hegel's science of logic (A.V. Miller, Trans.). London: Allen \& Unwin.

Hegel, G.W.F. (1977). Phenomenology of spirit (A.V. Miller, Trans.). Oxford: Clarendon Press.

Hirst, P.H., \& Peters, R.S. (1970). The logic of education. London: Routledge \& Kegan Paul.

Kemmis, S., \& Carr, W. (1983). Becoming critical: Knowing through action research. Victoria: Deakin University Press.

Kundera, M. (1984). The unbearable lightness of being. New York: Harper \& Row.

Marx, K. (n. d). Capital: A critical analysis of capitalist production (S.M. Moore \& E. Aveling, Trans.; F. Engels, Ed.). Moscow: Progress.

Merleau-Ponty, M. (1962). Phenomenology of perception (C. Smith, Trans.). London: Routledge \& Kegan Paul.

Merleau-Ponty, M. (1968). The visible and the invisible (A. Lingis, Trans.). Evanston, IL: Northwestern University Press.

Neiman, A. (1991). Comments of Garrison on Greene: Does metaphysics really matter for practice? Educational Theory, 41(2), 213-219.

Noddings, N. (1984). Caring: A feminine approach to ethics and moral education. Berkeley, CA: University of California Press.

Noddings, N. (1989). Women and evil. Berkeley: University of California Press.

Peters, R.S. (1966). Ethics and education. London: Allen \& Unwin.

Phenix, P.H. (1964). Realms of meaning: A philosophy of the curriculum for general education. New York: McGraw-Hill.

Sartre, J.-P. (1956). Being and nothingness; An essay in phenomenological ontology (Hazel Barnes, Trans.). New York: Philosophical Library.

Sartre, J.-P. (1960). Introduction to Les temps modernes (F. Ehrmann, Trans.). In E. Weber (Ed.), Paths to the present: Aspects of European thought from romanticism to existentialism (pp. 432-441). New York: Dodd, Mead.

Sartre, J.-P. (1968). Search for a Method (H. Barnes, Trans.). New York: Random House.

Sartre, J.-P. (1974). Between existentialism and Marxism (J. Matthews, Trans.). London: NLB.

Sayers, S. (1985). Reality and reason: Dialectic and the theory of knowledge. Oxford: Blackwell.

Smith, M. (1985). The materialist dilemma: Education and the changing of circumstances. Philosophy of Education 1984 (pp. 241-251). Normal: Illinois State University Press.

Stewart, D., \& Mickunas, A. (1990). Exploring phenomenology: A guide to the field and its literature. Athens: Ohio University Press.

Vandenberg. D. (1971). Being and education: An essay in existential phenomenology. Englewood Cliffs, NJ: Prentice-Hall.

Vandenberg, D. (1990). Education as a human right: A theory of curriculum and pedagogy. New York: Teachers College Press. 